\title{
Scientific Cum Doctriner Approach: A Collaborative Perspective in Islamic Studies
}

\author{
Widodo Winarso * \\ Faculty of Education and Teaching, State Islamic Institute Syekh Nurjati (IAIN Syekh Nurjati Cirebon); \\ Indonesia \\ * Correspondence: widodo@syekhnurjati.ac.id; Tel.: +62-813-2468-5073
}

\begin{abstract}
Islam is not a mono-dimensional religion, therefore studying Islam with all its aspects is not enough with the scientific method, ie philosophical, human, historical, sociological methods. Likewise, understanding Islam with all its aspects can not be-be doctrinaire. A scientific and doctrinal approach should be used together (Scientific Cum Doctrine).
\end{abstract}

Keywords: scientific cum doctrinaire; islamic studies

\section{Introduction}

The phenomenon of Islamic understanding of Islam is still marked by varied circumstances. Islam has many dimensions, ranging from faith, intellect, economy, politics, science and technology, environment, peace to the life of the household. In understanding the various dimensions of Islamic teachings requires various approaches Studied from various sciences. True science shows the right path of faith and belief towards the true teachings of Islam. If the Islamic approach is less comprehensive, there is a perception that is not intact, resulting in such varied conditions.

The method is used to produce a comprehensive and comprehensive understanding of Islam in order to guide Muslims in dealing with and responding to the varied teachings of Islamic teachings. The challenges facing Islam today are at least three, first, in the face of contemporary issues marked disorientation of values and degradation of morality, religion is challenged to emerge as an authentic moral voice; Second, religion must face the pluralism tendency, cultivate in new theological frameworks and Make it happen in the plural co-operation, and Third, religion emerges as a pioneer of resistance against all forms of oppression and unfaithfulness (Langgulung, 1988).

The journey of Islam until now has exceeded the period long enough and embraced by humans all over the world. Islamic studies can be likened to as a large and long river.Wajar if the source of the original water clear and clear and flowing on the narrow groove and swiftly on the way to the estuary increasingly widened, twisted and branched. The water is increasingly concentrated because it also carries mud and garbage. The movement becomes sluggish.

The illustrations, at least illustrate the fact that there is a movement of Islamic studies that are dynamic. An approach is needed to study the study. The approach is oriented towards the solution and solution of the morning of the problems of the ummah. In understanding Islam, a basic foundation is needed to study the Qur'an thoroughly.

In the order of scientific development that is the world of scientists. Sometimes the discussion of Islamic studies is always on the meaning of scientific justification. But not all dimensions of life can be interpreted only rely on the things scientists. A combination of religious approaches is needed. By doing both of these things, so in the study of Islam can understand the content of its content and will produce an understanding of Islam as a whole. For that in understanding and studying the teachings of Islam (Islamic studies) that exist in scientific books sometimes need to be observed whether this teaching is partial or whether it is comprehensive. 
The study of Islam must be seen from various dimensions. In this connection, Islamic studies can not be viewed only from one angle, but rather a view on various aspects. Aspects contained in the Qur'an if studied thoroughly will result in a thorough understanding of Islam. According to Shari'ati, here is a way of understanding Islam to be a scientific passion in itself:

1. By knowing God and comparing Him with the other gods.

2. By studying the Holy Book of the Qur'an and comparing it with other celestial books (or other celestial scriptures).

3. Studying the personality of the Apostle of Islam and comparing it with the great figures of reform who have lived in history.

Studying prominent Islamic figures and comparing key religious figures as well as other schools of thought (Syari'ati, 1982)

Furthermore, there is also an approach to understanding the Islamic study described by Nasruddin Razak. Similar to Shari'ati, Nasruddin Razak also offers methods of understanding Islamic studies as a whole. According to him, comprehending Islam thoroughly is important although not in detail. To understand Islam correctly, Nasruddin Razak proposed four ways of studying Islamic studies. The four ways are as follows.

1. Islam must be learned from its original source, the Qur'an, and Al-Sunnah Rasulullah.

2. Islam must be studied in an integral way, not partially, meaning the study of Islam is thoroughly studied as a unified whole not partially.

3. Islam needs to be studied in the library written by the great scholar, the $\mathrm{Zu}$ 'ama and scholars of Islam because in general, they have a better understanding of Islam.

Islam should be studied from the theological normative provisions contained in the Qur'an, and then connected with the historical, empirical, and sociological facts that exist in society (Razak, 1989).

To reinforce the above argument, another case according to Mukti Ali. He holds that during this approach to the study of Islam is still very limp. More innovative approaches are needed. One approach that can be made reference that combines two paradigm studies (collaborative perspective). According to him, the approach is the Scientific Cum Doctrine approach. In addition, another method proposed by Mukti Ali is the method of typology. This approach is widely used by Western scholars to understand the human sciences. In the case of Islamic studies, as well as other religions, the approach can identify five aspects or characteristics of the religion, and then compare with the same aspects and characteristics of other religions. The five aspects are 1) the divine aspect, 2) the prophetic aspect, 3) the scriptural aspect, and 4) the aspect of the circumstances of the prophet and the people he accused and the chosen individuals produced by that religion (Wilar, 2014).

From the above description, it can be seen that in the methodology of Islamic studies that can be used to understand the Islamic religion outline there are two. The first method of cooperation, that is to understand Islam by comparing all aspects that exist in other religions so that it will produce an understanding of Islam objectively and intact. Second is the method of synthesis, meaning a way of understanding religion by integrating science and dogmatic in an approach that is interpreted by the Scientific Cum Doctrine's approach.

In line with the spirit of understanding of Islamic studies, the writer is interested in studying the Scientific Cum Doctrine approach.

\section{Literature Review}

\subsection{Islamic Studies Approach; Religious and Religious Studies}

Religion moves in the normative-doctrinal region because it is born from the value or the source of divinity. While religious is the activity of meaning and the manifestation of the normative religion into the historical-cultural area by its adherents. Thus religion and religion clearly differ significantly and should not be equated although in some cases the term religion can also include in it religious meaning in addition to its own meaning. Therefore it is necessary to clearly understand 
the difference between religious research (research on religion) and religious research (religious research).

\section{Research on religion}

Research is a systematic and objective effort to study a problem and find general principles. While religious research makes religion as a research object that has long debated. The religionist is inclined to believe that religion has the absolute truth so it does not need to be examined (Sumardi,1982). Religion contains two groups of teachings, namely:

a. The basic doctrine revealed by God through His Messenger to human society. Such basic doctrines are found in the scriptures. The teachings contained in the Holy Scriptures require an explanation of the meaning and manner of their execution. The explanations of the leaders or religious scholars from the religious teachings of the group.

b. The basic doctrine of religion, because it is a revelation from God, is absolute, absolutely true, eternal, unchangeable and immutable. While the explanation of religious scholars against the basic teachings of religion is only an explanation and the results of thought that are not absolute, not absolutely true, and not eternal. This second form of religious teaching is relative, relative, changing and can be changed in accordance with the times.

Scientists think that religion is an object of study or research because religion is part of cultural social life. So, religious research is not researching the nature of religion in the sense of revelation, but researching people who live, believe and gain influence from religion. Thus the position of religion religious research is parallel to other studies, which distinguishes only the object of the studies examined.

Religious research emphasizes religious material as its target; Namely religion as doctrine. This type of research directs its activity on the doctrine or religious text which in fact is normative. There are four sectors that are dealt with by religious research, namely (1) religious institutions, ie bodies that perform the duties of religion, (2) religious relationships, including the relationship between the individual or group of internal religion itself or between various religions, (3) ) The function of religion, ie the extent to which religion affects the life and life of individuals or societies, and (4) religious texts (written materials on religion) and religious documents (everything written, photographs, sculptures, buildings etc.) religion).

Based on this view can be interpreted about the explanations of the teachings contained in the holy books by the leaders or religious experts to form the second group of religious teachings are relative, relative and can be changed in accordance with the times when not in accordance with the teachings of Islam, as For example the Prophet explained the ordinance of prayer, whereas in the holy book is not explained the way of prayer and prayer is itself qath'i / can not be changed.

\section{Religious Research}

While religious research, ie research that the object is not directly about the doctrine of religion, but emphasize on religion as a religious system and the values covered and the symptoms that occur such as the value of humanity, harmony, and social interaction.

M. Atho Mudzhar says that the difference between religious research and religious research needs to be based on the differences that distinguish the types of research methods required. For religious research which is the target is religion as a doctrine, the door to the development of a separate research methodology is already open, even there are already pioneering. The existence of ushul fiqh science as a method of legal istinbat in Islam and science of musthalahul hadist as a method to assess the accuracy of the words of Prophet Muhammad SAW is proof that the desire to develop a separate research methodology for the field of religious knowledge has ever emerged. The next issue is whether we want to perfect it or eliminate it completely and replace it with a new one, or not by replacing it altogether and leaving it unavailable (Mudzhar,1998).

As for religious research that targets religion as a social phenomenon, it is not necessary to make a research methodology alone. Simply borrow the existing social research methodology. 
Whereas according to Juhaya S. Praja, religious research is the study of the origin of religion, and the thinking and understanding of adherents Religion to the teachings contained therein. Thus, there are two areas of religious research, namely as follows (Praja, 2002).

a. Research on the source of religious teachings that have given birth to the disciplines of tafsir and the science of hadith.

b. Research and understanding of the teachings contained in the source of religious teachings.

While the study of religious life is a study of the practices of religious teachings conducted by humans individually and collectively. Based on these limitations, religious life studies include the following:

a. Individual behavior and its relationship with the community based on the religion it embraces.

b. The behavior of society or a community, whether the political, cultural or other behavior that defines itself as a follower of a religion.

c. The religious teachings that make up the social order, the style of behavior and culture of the religious community.

Social research on religion, according to Mukti Ali, only describes the reality-concrete religious phenomenon. It contains no reflection or religious response that should be placed in the entire research process. For that required cooperation between social science and religious science. Social science provides the material for religion, while religion will do religious reflection by finding meaning and interpreting the data and the phenomenon in light of religion (Ali,1965).

Islam is not a mono-dimensional religion, therefore studying Islam with all its aspects is not enough with the scientific method, namely philosophical methods, human sciences, historical, sociological and so on. Similarly, understanding Islam with all its aspects is not only doctrinaire. Scientific and doctrinal approaches should be used together or more popularly interpreted by Scientific Cum Doctrine.

In the discourse of contemporary religious studies, the phenomenon of human religiosity can be seen from various angles of approach. It can no longer be seen only from the point of view and solely in relation to the normativity-the historicity of the understanding and interpretation of the person or group to the norms of the religious teachings he embraces, and the models of deeds and practices of the religious teachings he performs in daily life- day. The teachings of revelation, but also can be seen from the angle and closely related to the concept of science.

In relation to religion as the object of research, at the earliest stage, it must be realized that religious research as an academic business which means making religion as the target of research. Methodologically religion should be made as a real phenomenon, however, it may seem abstract religion. From the point of view above, then perhaps can be formulated 5 (five) categories of religion as a phenomenon that became the subject matter of research, namely: a). Scriptural texts, b). Religion as a product of thought, c). Religion as a product of social interaction, d).Agama in the form of religious institutions, and e). Religion in the form of religious symbols (tools/merchandise).

\subsection{Methodological aspects of Islamic studies; Intellect A. Mukti Ali}

According to the view of A. Mukti Ali's thoughts on Islamic study, the methodology can be grouped into 3 kinds. Adapaun three kinds of groups that include the following.

\subsubsection{Use of Scientific Methods and Social Sciences in Religious Research}

Mukti Ali introduced the use of scientific methods in religious research in the 60's decade. The scientific oration he delivered in 1964 entitled Comparative Religion (A Discussion of Methods and Systema), though in the context of Comparative Sciences, is an early phase of his idea of the importance of scientific methods in religious studies. In this book, Mukti Ali introduces several methods or approaches in the scientific study of religion. In his discussion of the Comparative Science of Religion, he draws distinctions between the apologist and scientific approaches. According to him, the comparative study of religion is neither apology nor a tool for maintaining one's beliefs and 
religions, but a comparison of religion is a tool for understanding the functions and characteristics of religion (Ali, 1965).

Religious comparison, according to Mukti Ali, should be placed in conjunction with other branches of the Science of Religions. He introduced three branches of Religious Studies. First, the History of Religion (history of religion), a science that studies the facts of religion and seeks to assess historical data to get a clear picture and understanding of religious experience. To understand the development of religion, History of Religion uses other auxiliaries such as Anthropology, Sociology, Psychology, Archeology, and others. Second, Comparative Religion, a science that seeks to understand the findings of religious history by comparing religions to find the fundamental structure of religious experiences and religious concepts through analysis of similarities and differences. Third, the philosophy of religion, the branch of religious science that seeks to draw conclusions from the facts collected by the History of Religion and compared by Comparative Religion in the arena of philosophy (Ali,1992).

Mukti Ali's explanation above shows the existence of relation and dependence of several branches of Religion in understanding religion. Comparative Religion depends on the information found by the history of religion. Information from the History of Religion becomes a comparison material to see the similarities and differences of certain aspects of a number of religions. From the history of religion and comparative religion then become an important material for the philosophy of religion to make philosophical meanings of religious facts that (Rahmadi, Jaferi, \& Djazimah, 2014).

In addition to introducing briefly the three branches of Religious Studies above, Mukti Ali also put forward several methods of studying and researching religions. Some methods (methods) are methods of Philology, Anthropology method, Sociology method, and historical method (Ali,1992).

After introducing the use of scientific method in the study Religion, Mukti Ali emphasizes the importance of cooperation between Comparative Religion and the social sciences to understand and interpret religious phenomena. He stated that to get the material, the tools of research, and the improvement of the method of Comparative Religion much depends on other sciences, such as Prehistory, History, Archeology, Geography, Physical Anthropology, Ethnology, Psychology, Philology, Sociology, Social Psychology, Criticism Scripture and other knowledge including economics, law and political institutions. According to him, along with the development of the theory and methods of social discipline, there needs to be a synthesis of the interrelated sciences in interpreting religion.

The difficulty of using the scientific method in the religious study according to Mukti Ali is how to be objective in studying religion without one-sidedness. Another difficulty is the difference in concepts one uses in approaching religion that impacts on the different outcomes achieved.26 Mukti Ali sees similar difficulties experienced by Muslims in Indonesia. Because according to his judgment, studies of religions (in the 1960s) still use apologist and polemical approaches, not objective scientific approaches.

In the decade of the 60s, Mukti Ali's thought about the need for a scientific method and the use of social sciences in studying religion was still considered foreign by Muslims. Therefore he tried to convince Muslim readers of the possibility of using Comparative Religion with his scientific method of studying religion without sacrificing the truth of Islam. He even convinced that by studying other religions Muslims (muballigh and Muslim scholars) would find the finality and perfection of the Qur'an and Islam. Muslims will find the location of Islam's advantages over other religions which in turn will increase confidence in Islamic teachings. But he also warned that the Comparative Science of Religion also poses a danger to Islam if it is wrong to use it. But on the contrary, if this science is used correctly, this science will greatly help the development of Islam because the expansion of Islam will be stronger than ever (Ali,1992).

He also tried to convince the Muslims not to mention only the apologist and polemical way of defending Islam, but also to resort to a scientific approach in understanding the religions, especially Islam itself. This method not only deepens belief in Islam but also raises mutual respect for other 
religions. He suggested that Muslims put aside the nonsensical prejudices against other religions so that scientific investigation can be done by Muslims (Ali,1992).

Mukti Ali's thought above is the initial stage of his methodological idea addressed to Muslim readers in the decade of $60 \mathrm{~s}$ where when the thought was conveyed, as mentioned earlier, they are still unfamiliar with the use of scientific methods and the social sciences in studying the religions. This condition "forced" Mukti Ali himself to use an apology as well to convince Muslims to switch from polemical apologist to scientific studies.

Some of the above explanations show that religious studies, in the context and perspectives of the Comparative Religion Sciences, should be conducted with the following references. First, religious research is conducted using scientific methods and done objectively (not one-sided). Second, scientific religious research demands No apologist-polemical approach in religious study. Third, religious research should use the methods of social science humaniora by synthesizing various sciences in interpreting religion.

\subsubsection{Religious Research: Objects, Researchers, Stages, Types and Methods}

In his article entitled "Religious Research (A Discussion of Methods and Systems)" Mukti Ali states that the object of religious research is the act of religious people, namely the extent of religious teachings embodied in relationships among fellow human beings in the community life. Thus there is a relationship and the influence of reciprocity Between the development of religion and society that should be the target of research that should be the target of religious research (Ali, 2008; Abdullah, 2001; Alagappa,1995).

There are four sectors that are dealt with by religious research, namely (1) religious institutions, ie bodies that perform the duties of religion, (2) religious relationships, including the relationship between the individual or group of internal religion itself or between various religions, (3) ) The function of religion, ie the extent to which religion affects the life and life of individuals or societies, and (4) religious texts (written materials on religion) and religious documents (everything written, photographs, sculptures, buildings etc.) religion) (Ali,1965).

Elsewhere, Mukti Ali mentioned that religious research in the context of comparative religion is a religious experience. The experience of religion is expressed in three forms. The first form is the theoretical or intellectual expression (including theology, cosmology, and anthropology). The second form is the practical expression or practice (worship). The third form is the sociological expression, the social expression (Ali,1992).

The object of religious research as mentioned above, according to Mukti Ali often have similarities with the object of study of the social sciences, namely the relationship between humanity and society. Due to the similarity of this object, not infrequently between the science of religion and the social sciences review the same object with their methods and approaches. Is it possible that religious and social sciences work together in working on religious phenomena that are the object of religious research.

In his article entitled "Religious Research in Indonesia", Mukti Ali describes the tendency among social scientists and religious scholars to approach each other and establish cooperation in researching religious phenomena. Among social scientists, there is a tendency to examine religious issues and vice versa among experts The science of religion appears the tendency to examine religion by using science and social science methodology.This tendency, he argues, is something positive to cover each of the deficiencies.Causes of social scientists feel not enough just to study and understand the religious phenomenon based only on the perspective of social science only Without involving religious perspectives.In contrast, among religious scholars also emerged the awareness that studying religious phenomena is not enough to only use theoretical speculation or using deductive methods, but also required empirical and inductive methods in understanding religion as it is done in Social Sciences (Ali,1992; Sumardi,1982).

According to Ali, religious research is related to religious reflection on experiences in concrete situations with religious attitudes. Reflection of religion is a reflection of religion itself and reflection 
in religion. In this case, it is necessary to understand the teachings of religion itself and how the manifestation of religion in the life of society. Researching religious communities means examining the symptoms closely related to the symptoms of religious communities. How to diagnose the symptoms is similar to how data collection in Sociology. But the gatherers of that data are not Sociology merely because religious people interpret the symptoms in that society in the light of their religious teachings. So religious research not only exposes the data but at the same time interpreted it (Ali,1992).

Social research on religion, according to Mukti Ali, only describes the reality-concrete religious phenomenon. It contains no reflection or religious response that should be placed in the entire research process. For that required cooperation between social science and religious science. Social science provides material for religion, while religion will do religious reflection by seeking to mean and interpreting the data and symptoms in the light of religion.

The next important aspect that gets emphasis from Mukti Ali is the factor of the researchers. For him, the researcher factor has more important role in the research than the research method. The research method is an important aspect that can not be abandoned in the research. But the method aspect is not a guarantee that the research The method of the depth of understanding in understanding social and religious issues, personal integrity, sensitive in perception, discipline in imagination, and reserve in mental clearly leads to the importance of a person, Therefore, discussing research not only talks about strategy and research techniques but also personal factors of scientific researchers.

The researcher factor also becomes important because it deals with aspects of interpretation of social facts that are somewhat influenced by the background of the researcher. According to him, the interpretation of social facts contains many interpretations. The interpretation depends on the researcher's questions and the background of the researcher. Muhammad's proof does not agree that the phenomenon of religion can be understood or interpreted well by researchers who have no religious background. In this case, Mukti Ali writes:

In this connection, we want to emphasize an element so that all of his empirical approaches are colored, ie the attitudes of religious researchers. The religion in humans is so personal and deep that it can only be observed with caution. A researcher who is as good as a business may be very good may not be able to find religious issues to the interviewee or research unless he himself has faith and reflection, not only on the situations where the research is conducted but also outside the research context in daily life.

If the researcher is not a religious person, in the end, he is only able to conjure expressions of beliefs and religious phenomena, but not faith or religion itself. Perhaps in a certain sense sociology and psychology have been satisfied with finding these symptoms. But it is precisely in religious research that these phrases and phenomena can not be accepted by face-value. In religious research, reflection needs to be done. May be done if the researcher does not know the intricacies of the main issue of religion. Therefore research and also the field workers in the field of religion itself must be religious and reflect on his religion. And here is precisely the difference between religious research with the sociology of religion and religious psychology (Ali,1982).

Elsewhere, Mukti Ali again emphasized the importance of religious researchers, as he put it this way: In the concept of religious research, this reflection has already begun to take place in the field of research. How is it possible that field workers, interviewers, for example, do not know anything about the fundamental issues of religion? Then this kind of person can not be used in the process of religious research. We, therefore, emphasize a demand that the investigator as well as the field workers and so on his own religion and reflect on his religion (Ali,1965).

For him, the researcher is a subject that can be involved in his own faith research. Therefore, objectivity or neutrality, he argues, is not the main and only criterion in the process of religious research, but subjective judgment is also an important element and is a critical criterion in the research process. On this basis, Mukti Ali's view of the element of reflection of a subjective researcher 
of religion does not preclude and diminish the scientific value of religious research. But precisely with this kind of reflection phenomenon can be understood in a more appropriate language.

In addition to requiring researchers to be religious and able to carry out religious reflection on the religious phenomena studied, Mukti Ali also provides additional criteria or additional completeness for researchers who want to research or understand other religions than the religion it embraces. First, the completeness of its intellectual property, namely the completeness of information about the learned religion and mastery of the language of religion studied. If the researcher does not master the language of religion or scripture in question can be done through translation. Secondly, enough emotional Condition, that is trying to understand the religion of others Must involve "feeling", attention and participation. To generate a sense of participation, researchers should have some experience with the adherents of the religion studied. This social experience will help researchers understand the religion of the learned believer. Third, will. The researcher must have a willingness to understand the religion of others with purpose and constructive orientation. Fourth, experience, extensive human experience. Such experiences will add to the qualifications of researchers to understand religions that are not their own, because they can connect people's thoughts with behaviors, feelings, and ways of thinking, especially in the way of religious people (Ali,1965).

In relation to the stages of research, in essence, according to Mukti Ali, religious research methods should be colored and contain religious traits. It is that religious research is based on religious matters and that the process of diagnosis and prognosis is directed by one of the evaluation schemes taken from religion.

The application of this approach in operational religious research, according to Mukti Ali, is carried out through the following stages: (1) carefully observing the facts, (2) determining where the most prominent possibilities exist, ie trying to understand what the facts mean (3) based on a rational understanding at stages 1 and 2 trying to see in light of religion, and (4) judging in the light of the religion of concrete execution according to the historical situation. 42 These four stages when viewed from the perspective of the scientific cum doctrinaire approach, as will be discussed In the next section, shows that stages 1 and 2 use the scientific method (data filtration stage) in stages 3 and 4 using doctrinal methods (interpretation stage).

The next aspect which is also put forward by Mukti Ali is about the three types of research that are appropriate for use in religious research using the method of social sciences. First, the type of descriptive research. Here he presents three features of research in the social sciences, namely description, exploration and verification. The differentiation of these three patterns of research lies in the role of hypotheses. Hypotheses are not used in descriptive research; A new hypothesis was formed at the end of the study on exploratory research, And the hypothesis is the starting point to be tested on the new but wants to portray one of the social groups and the symptoms in the religious community. On this basis, he argues that the type of descriptive research that does not use hypotheses is more suitable for religious research. Second, grounded theory. This research is not through the process of hypothesis testing that has been established before then verified, but the research itself tried to bring the theory from the research. According to him, this type of research in addition to meet the demands of the specificity of religious research is also in accordance with the development of modern social science. Third, action research.Type this research is a combination of social action (affect and change social circumstances) with research; In other words a combination of acting and knowing. This kind of research needs to be used because, according to him, the involvement of the researcher as a religious person and who reflects in the field of religion requires this type of research (Ali,1965).

In the aspect of the method used in religious research that uses the scientific method usually used in the social sciences, Mukti Ali proposes several methods or techniques that can be used as consideration for use in religious research. Some methods or techniques are personal documents, questionnaire, Interviews, public opinion polls, observations, and others. Personal documents can be examined using nomothetic approaches if the numbers are large and idiographic approaches if the document is only one or a few. The idiographic approach also has scientific weight if supported by 
other sources. Questionnaires, interviews and public opinions polls that are standard or open may be considered for use in religious research. As for observation (sociological and anthropological), it is suggested to use participant observation. Other methods that are also recommended for consideration are the method of comparative religion, the genetic approach (researching the growth of religion), the graphs and statistics.

The ideas of research methods or techniques suggested by Mukti Ali above suggest that they support the use of qualitative and quantitative approaches and methods in religious research. The nomothetic terms, statistics, and use of questionnaire techniques, public opinion polls are included in the tradition of quantitative research, while the idiographic and participant observation techniques are part of the qualitative tradition.

\subsection{Scientific-cum-Doctrinist Approach: Method of Synthesis in Religious Research}

Associated with religious research through the methodological thought of A. Mukti Ali ie with Scientific Cum Doctrine approach. It is necessary to take a multidisciplinary and nonconventional approach in religious studies and separate this study from theological judgments (Ali,1965).

This thinking is based on the fact that there are a number of variants of thought related to the application of methods in religious studies that need to be searched for. In this case, Mukti Ali proposes three variants in the use of religious study methods.

According to A. Mukti Ali, the three variants were among them; First, the flow that emphasizes that the approach to religion should be Sui-Generis and can not be attributed to methods in other fields of science. Secondly, the flow that states however and whatever the problem under the study of the legitimate method to be used is the scientific method. The term "scientific" is here used in a double sense: in a narrow sense indicating the methods used in the natural sciences; And in a broad sense, refers to a procedure that works with the logical and intact discipline of the obvious premises. Third, the flow that requires the synthesis method in the study of religion, which is a combination of Sui-Generis method and scientific method (Rahmadi,2016).

By referring to these three variants, it is understood that the second flow in favor of the scientific method in the study of religion opposes the existence of pluralism and the dualism of such methods. Proven Ali chose the third method, that religion should be examined using the combined method. Wherein the lack of many theologians and philosophers has proved inadequate narrow scientific approach to the study of religion. According to him, many prominent scholars question the validity of the application of experimental methods and techniques, quantitative and causal research to the spiritual world. In order for the method of religious studies to be precise then the method used must be in accordance with the object under study, namely religion.Implikasiasinya, individual phenomena, the nature of value, And the meaning of freedom must be acknowledged. Researchers who do not provide concessions to methods that accommodate this aspect will be closed to personal religious life.

Furthermore, Mukti Ali put forward some of the methods or approaches that have been used in religious studies. First, the historical approach, an approach that seeks to trace the origins and growth of religious ideas and institutions based on periods of particular development as well Trying to understand the forces that exist in that religion in a certain period in the face of various problems. Religious historians often use archaeological and philological research in studying religion. Where the object under study that is monuments and evidence of literary from the past. The second, psychological approach used by psychologists, is an approach that seeks to understand the inner side of religious experience where and whenever that experience occurs. This approach also seeks to understand individual feelings and groups along with its dynamics. Third, the sociological approach, This was originally using the s method General ideology initiated by a sociologist who was later corrected by the founder of the sociology of religion. Fourth, the approach of religious phenomenology which, according to Mukti Ali itself is a new method in the study of religion. This 
approach aims to look at religious ideas, practices, and institutions Taking into account its objectives without relating them to philosophical, theological, metaphysical or psychological theorists, and Fifth, the typological method which is the bridge between empirical and normative research. The phenomena gave by history, psychology and the sociology of religion must be regulated.To this, it takes typological categories.The arrangement of these types is intended to provide a better understanding of the history of religion. The types of myths, theology, worship, the charism of religion, the leadership, the grouping and the religious authority are some of the types studied by typological approach (Ali,1992).

Some approaches or methods that have been mentioned above according to Mukti Ali itself is not enough to understand religion well. Such a scientific approach must be accompanied by a dogmatic approach as follows:

Sticking to the stand on the necessity of a synthesis approach, scientific approaches, historical, archaeological, philological, sociological, phenomenological, typological and other approaches must be accompanied by a "dogmatic" religious approach. Thus the "religious-scientific" or "scientific-cumdoctrinaire" or "scientific-religious" approach should be used in approaching religion (Ali,1992).

There are different starting points and results from religious studies with religious-scientific (religious-scientific) scientific and religious approaches. The sociology of religion as an example, although working on the same data and may also use the same method, the sociology of religion with a scientific approach only see the data sociologically while the religious sociology departing from the religious discipline look at the data religion-scientific.

According to Ali, it is not a simple matter to define what it means by looking at scientificallyreligious data. Religious Sciences (religions Wissenschaft) are different from normative disciplines because they have no speculative objectives and also do not depart from an a priori deductive method. Although the principle of religious studies is descriptive, the research should be directed to the meaning of religious phenomena. The understanding lies in Trying to understand the essence of this phenomenon by means of physiology, psychology, sociology, economics, language, art, or other studies. With the narrow sense that religion can not only be explained by using the perspective of social, linguistic or economic functions.

Not only in the study of religion, Mukti Ali also suggested that the method of synthesis is also used in Islamic studies. According to him, one method alone is not enough to study Islam, because Islam is not a monodimensional. Maji religion of Islam with its various aspects is not enough by using scientific methods alone, So too can not be only doctrinally. But the scientific and doctrinal approach must be used together. The scholars (including the Orientalists), he argues, approach Islam by using the scientific method alone. It seems, though interesting but in fact, they do not have a complete understanding. They only know the external aspects of Islam. In contrast, scholars are accustomed to understanding Islam in a doctrinal and dogmatic way, which has nothing to do with the reality of society so its interpretation can not be applied in society. Therefore, the scientific-cumdoctrinaire approach should be used, the scientific-cum-subgenres approach should be applied. This is what the synthesis method means.

Elsewhere, as suggested by A. Singgih Basuki, Mukti Ali posted three approaches in Islamic studies. First, the scientific approach, which is approaching religion scientifically, refuses this approach if only used singly because it is considered unsuitable. Secondly, the dogmatic approach of approaching religion is based on Qur'anic and hadith statements. Third, scientific and doctrinal approaches, such as sociologically but also Qur'ani, anthropologically but also with hadith explanations, philosophically and Qur'ani. This is the synthesis or Integrals developed and considered ideal by Mukti Ali (Rahmadi,2016).

Thus, that religious research must use scientific methods that are conducted objectively without involving elements of apologists-polemic in it. The Scientific method used may use scientific methods used in the social sciences or cooperate with the social sciences in the study of religion. However, the use of scientific methods and the social sciences is not sufficient to understand religious 
phenomena. The religious reflection in understanding religious phenomena must be involved so that the interpretation of the phenomena can be in harmony with the religious language.

\subsection{Dimensions of Scientific Cum Doctriner Approach to Islamic Studies}

To understand this approach, some of the dimensions of the Mukti Ali scientific-cumdoctrinaire approach as described by Waryani Fajar Riyanto (with some modifications) may at least help to see several sides of this approach, as shown in the following table 1 (Riyanto, 2013; Abdullah,2006).

Table 1. The Dimension of the Scientific Cum Doctrineiner Approach (Mukti Ali)

\begin{tabular}{|l|l|}
\hline Methodology & Synthesis (Scientifik-cum-doctriner) \\
\hline nature & Scientific- dogmatic \\
\hline Nature of the findings & Objective-cum-Subjective (Phenomenological Truth) \\
\hline form & Dyadic \\
\hline Multiple patterns & Al-Qur'an and Islam history (Normative-Historical) \\
\hline Classification of Science & Religious scholarship, social science, natural science \\
\hline Era & modern \\
\hline The idea of religious studies & Comparative religion \\
\hline Theory of humanities & Agree in Disagreement"tolerance" \\
\hline sect "mazhab" & Islamization of science \\
\hline
\end{tabular}

According to Amin Abdullah pointed out that empirical research of religious phenomena can not stand alone. Where still needed the understanding of the "internal" aspect of religion to understand the dimensions of normativity. This is what Mukti Ali calls "scientific cum doctrine" (Abdullah,1996).

This synthesis method is an alternative method that becomes the middle way between generic sui method and the scientific method or the merging of scientific method with the theological method. In this method doctrine and religious language are used as 'analytical tools' to understand religious facts (Kahmad,2000).

Thus, the doctrinal or religious dogma of the scientific-cum-doctrinaire approach is not intended to exercise judgment on religious behavior and other religious doctrines. Similarly not to show superiority or imperforates between one religion with other religions. But doctrine aspect is used to understand a religious phenomenon by referring to religious doctrine that is in harmony with the religious phenomenon that can be understood based on religious language. So need to be developed the related idea of scientific-cum- Doctrine. First, continue and fill the idea of scientificcum-doctrine. The idea still needs to be developed, such as how to work and so forth. Second, look for a new synthesis again to be developed to fill the scientific-cum-doctrine concept.

\subsection{The influence of the scientific cum doctrine approach on Islamic studies in Indonesia}

Associated with the development of the dimension of the significance of scientific methods within the scope of Islamic studies today, the use of an Islamic study approach is always open. The context of openness in question is that an approach needs to be analyzed and reviewed continuously. This provides the science of a dynamic nature that will someday change.

By academic convention, any review topic will be considered correct if it is in accordance with the method that has been formulated in accordance with the predetermined topic. Nevertheless, every reviewer of Islamic studies is required to conduct a study with the critical thinking method, not only fixated on the particular method of thinking used or the object of thought which is the focus of the study. Even from the results of existing Islamic studies - ideally - can always be produced nuances or methods and conception of new Islamic thinking. This is in line with the tendency of 
postmodernism and postcolonial theory, where reader / qdri becomes far more important, More than just texts and authors (muqallid).

However, regardless of the above conception. An Islamic study approach must have an influence on the development of Islamic studies itself. The results of one's thinking (religious figures/scientists) contribute to the progress of civilization in his time.

An approach/method of thinking - including Islamic thought - is at least influenced by seven factors: first, the cohesiveness factor that brings the idea. Second, the power of ideas developed that are rational and argumentative. Third, the momentum of history that gives the opportunity to develop the idea, or in other words the idea is in accordance with the needs of the times. Fourth, the literature containing ideas or methods of thought is marketed widely. Fifth, followers (supporters) or students and ideas bearers who have studied with it, who directly or indirectly helped develop the idea. Sixth, the idea that is raised is actually so interesting to be the study material. Seventh, the development of an idea is inseparable from the role of important and scientific forums (seminars, study centers) and so on. Similarly, the media publications (mass) as a medium for the transformation of ideas or conceptions of thought (Azhar,2009).

So in the context of Islamic studies, this approach literally consists of two important aspects, namely scientific and doctrine. Scientific has a scientific meaning and doctrine is understood as a doctrine or doctrine. In other words, in the approach applied the scientific method united with the doctrine or teachings contained in a religion, especially in the study of Islam. In this case, Mukti Ali wants to try to apply the scientific method to be a tool for researching a religion. The example of an application in Mukti Ali's thinking is evident from the way he tried to develop madrasah education as well as the Institute of Islamic Religion in order to align with the common educational institutions on the record that both are capable of applying scientific methods.

This approach is considered revolutionary because Mukti Ali tries to change the perspective that has long been built on the teachings of previous scholars who only understand the teachings of Islam only in terms of dogma and just doctrine. so than that he tried to combine the doctrine with scientific methods so that a study is said to be able to meet Criterion of a scientific knowledge.

\section{Conclusion}

A proposed alternative approach to Islamic studies is what A. Mukti Ali calls the Scientific Approach-the doctrinaire or the scientific-cum-subgenres approach, these two approaches are also known as synthesis methods. This method is necessary so that in seeing Islam not only one dimension of the phenomenon of Islam that multi faces. Although it is not wrong to observe Islam in a single face, it is not enough to cover Islam comprehensively.

The Qur'an as an inspiration for the development of the treasures of Islamic sciences itself is one proof of this, that Al-Quran contains all dimensions. For example, one dimension contains linguistic and literary aspects of the Koran, has given birth to the disciplines Language and literature that became the field of study for Arabic linguists and satrs. Another dimension is the philosophical themes and creeds of the Qur'an has been studied in depth by the philosophers and theologians in the disciplines of philosophy and theology of Kalam. In addition, there are still other dimensions in the Qur'an that have not been so thoroughly compared with other studies, namely the human dimension, which contains historical, sociological and psychological problems. This dimension is still not fully studied because of the Discipline- Discipline and other human sciences are much easier than, say one of them is the science of alam.dengan doing a combination of dogmatic approach with the scientific than the results of a comprehensive study.

A proposed alternative approach to Islamic studies is what A. Mukti Ali calls the Scientific Approach-the doctrinaire or the scientific-cum-suigeneris approach, these two approaches are also known as synthesis methods. This method is necessary so that in seeing Islam not only one dimension of the phenomenon of Islam that multi faces. Although it is not wrong to observe Islam in a single face, it is not enough to cover Islam comprehensively. 
The Qur'an as an inspiration for the development of the treasures of Islamic sciences itself is one proof of this, that Al-Quran contains all dimensions. For example, one dimension contains linguistic and literary aspects of the Koran, has given birth to the disciplines Language and literature that became the field of study for Arabic linguists and satrs. Another dimension is the philosophical themes and creeds of the Qur'an has been studied in depth by the philosophers and theologians in the disciplines of philosophy and theology of Kalam. In addition, there are still other dimensions in the Qur'an that have not been so thoroughly compared with other studies, namely the human dimension, which contains historical, sociological and psychological problems. This dimension is still not fully studied because of the Discipline- Discipline and other human sciences are much easier than, say one of them is the science of alam.dengan doing a combination of dogmatic approach with the scientific than the results of a comprehensive study.

\section{References}

1. Abdullah, M. A. (1996). Studi agama: normativitas atau historisitas?. Yogyakarta: Pustaka Pelajar.

2. Abdullah, M. A. (2006). Islamic Studies di Perguruan Tinggi: Pendekatan Integratif-Interkonektif. Yogyakarta: Pustaka Pelajar.

3. Abdullah, T. (Ed.). (2001). Nasionalisme dan Sejarah. Bandung: Satya Historika.

4. Alagappa, M. (1995). Political legitimacy in Southeast Asia: The quest for moral authority. Stanford University Press.

5. Ali, A. M. (1965). Ilmu perbandingan agama (sebuah pembahasan tentang methodos dan sistima) (Vol. 1). Bekasi: PT al-Falah.

6. Ali, A. M. (1982). Penelitian Agama di Indonesia" dalam Mulyanto Sumardi (ed), Penelitian Agama, Masalah dan Pemikiran. Jakarta: Sinar Harapan.

7. Ali, A. M. (1992). Ilmu Perbandingan Agama: Dialog, Dakwah, dan Misi. Jakarta: INIS, 226-231.

8. Ali, H. M. (2008). Penelitian Agama (Suatu Pembahasan Tentang Metode dan Sistem). Yogyakarta: Perpustakaan UIN Sunan Kalijaga.

9. Azhar, M. (2009). Metode islamic studies: studi komparatif antara islamization of knowledge dan scientification of Islam. Jurnal Mukaddimah, 15(26). 59-72

10. Kahmad, D. H. (2000). Metode penelitian agama: perspektif ilmu perbandingan agama untuk iain, stain dan ptais. Bandung: Pustaka Setia.

11. Langgulung, H. (1988). Pendidikan Islam Menghadapi Abad ke-21. Jakarta: Pustaka Al Husna.

12. Mudzhar, A. (1998). Pendekatan studi islam: dalam teori dan praktek. Yogyakarta: Pustaka Pelajar.

13. Praja, J. S. (2002). Filsafat dan metodologi ilmu dalam Islam dan penerapannya di Indonesia. Jakarta: Teraju.

14. Rahmadi, R. (2016). Pemikiran metodologis A. Mukti Ali tentang penelitian agama. Jurnal Ilmiah Ilmu Ushuluddin, 14(2), 107-124.

15. Rahmadi, R., Jaferi, H., \& Djazimah, H. (2014). Dinamika Pemikiran Sarjana Muslim tentang Metodologi Studi Agama Di Indonesia kajian terhadap literatur terpublikasi tahun 1964-2012. Iain Antasari Press.

16. Razak, N. (1989). Dienul Islam. Bandung: Al-Ma'arif.

17. Riyanto, W. F. (2013). Integrasi-Interkoneksi Keilmuan Biografi Intelektual M. Amin Abdullah (1953...), Person, Knowledge, and Institution. Yogyakarta: Suka Press

18. Sumardi, M. (Ed.). (1982). Penelitian agama: masalah dan pemikiran. Jakarta: Sinar Harapan.

19. Syari'ati, A. (1982). Tentang Sosiologi Islam. Terj. Saifullah Wahyuddin. Yogyakarta: Ananda.

20. Wilar, A. S. (2014). Truth and Method An Introductory Study on Mazhab Yogya's Methodology for understanding the Truth of Islam. Jurnal Studi Ilmu-ilmu Al-Qur'an dan Hadis, 15(2).291-319 